Western University

Scholarship@Western

Department of English Publications

English Department

2004

In Search of the British Indian in British India:

White Orphans, Kipling's Kim, and Class in Colonial India

Teresa Hubel

Huron University College, Canada, tdhubel@huron.uwo.ca

Follow this and additional works at: https://ir.lib.uwo.ca/englishpub

Part of the Literature in English, Anglophone outside British Isles and North America Commons, $\underline{\text { Race, Ethnicity and Post-Colonial Studies Commons, and the South and Southeast Asian Languages }}$ and Societies Commons

Citation of this paper:

Hubel, Teresa, "In Search of the British Indian in British India: White Orphans, Kipling's Kim, and Class in Colonial India" (2004). Department of English Publications. 128.

https://ir.lib.uwo.ca/englishpub/128 
Modern Asian Studies 38, 1 (2004), pp. 227-251. (C) 2004 Cambridge University Press DOI:10.1017/S0026749X04001064 Printed in the United Kingdom

\section{In Search of the British Indian in British India: White Orphans, Kipling's Kim, and Class in Colonial India}

TERESA HUBEL

\section{Huron University College, London, Ontario}

Contemporary scholars struggling to keep their work politically meaningful and efficacious often, with the best of intentions, invoke the triad of race, gender and class. But though this three-part mantra is persistently and even passionately recited, usually in the introductory paragraphs of a scholarly piece, 'attentive listening,' as historian Douglas M. Peers asserts, 'reveals that class is sounded with little more than a whisper' $(825)$. Unlike the other two, class largely remains an under-explored and, consequently, little understood category of experience and inquiry. I can say with certainty that this is true in my own field of postcolonial studies, with its subdiscipline of colonial discourse analysis. In part because of the politically justifiable emphasis on race in postcolonial research and theory (and only later, through feminist insistence, was that emphasis broadened to include gender), we have yet to develop as sustained, various, and subtle a critique of class as that which now exists for race and gender.

The reasons for this reticence or inability to pursue class as a category of analysis are myriad. ${ }^{1}$ But the fact that such a state of affairs exists in postcolonial studies can be determined simply by looking at recent scholarship on Rudyard Kipling's Kim, a novel that has garnered a good deal of attention in the postcolonial arena. One would think that this novel would cry out for, even demand, an interpretation that would be alive to class issues. After all, its protagonist

Acknowledgments

I am grateful to my friends who helped me with this essay-Brian Patton, Wendy Russell, Tom Tausky, and Neil Brooks-and to all the people who have listened to it, in its various forms, and who were interested and asked questions that made me think.

${ }^{1}$ In another place I have speculated on these reasons. See my article in Kunapipi, entitled 'Tommy Atkins in India: Class Conflict and the British Raj.'

oo26-749X/o4/\$7.50+\$0.10 
is working class and hence far outside the middle-class norm created by capitalist societies such as the British imperialist world delineated in Kim. But in virtually every examination of Kipling's novel written within the last 15 years, Kim's class is a fact hardly worth mentioning, much less a circumstance worth investigating and analyzing. ${ }^{2}$ The one recent postcolonialist work that both recognizes class as a legitimate subject in the readings of imperialist texts-generating as a result some beautifully faceted observations about the psychological underpinnings of sexual and social relationships that are organized by class, race, and gender-and also considers, if very briefly, Kipling's famous novel, is Anne McClintock's Imperial Leather, but, even here, Kim's class is ignored. Far from traditional in most of her readings of other texts, McClintock nevertheless takes a fairly typical stance when she interprets Kim as a 'narrative of racial passing' (69) that repudiates female sexuality.

There is no doubt that seeing Kim through the dual lenses of race and gender has produced some electrifying dissection of the historical ideologies that sustained the British Empire and continue to haunt many present-day ways of thinking. That we are unable, however, to engage in any depth in examinations of Kim's class, though the novel itself is absolutely upfront about this detail, points to a tender spot in our own university-trained psyches, a place we cannot probe without difficulty or one we might not want to fully acknowledge or we might not even be able to see, inhabiting, as many of us do, conceptual worlds that disavow class. Though disavowed, class and its inequalities influence the kinds of writing we study and the universities in which we teach. How important it is, therefore, in the face of this disavowal, and especially in such a politically conscious discipline as postcolonial studies, that we make the effort to understand this area of social life in all its abundant contexts. Hoping to claim class as a valid category of analysis and to contribute to a growing body of literary scholarship that incorporates class as well as gender, race, and sexuality into its theoretical universe, I will in this essay read Kim as a working-class protagonist created by a middle-class author writing out of and back to the highly stratified and hyper-masculinized colonial cultures of India and England at the

\footnotetext{
${ }^{2}$ See, for example, Said's chapter on Kim in Culture and Imperialism, Sara's Suleri's chapter in The Rhetoric of English India, the four articles by Christine Bucher, Brigette Wilds Craft, Feroza Jussawalla, and Don Randall in a special issue on Kim in the Journal of Commonwealth and Postcolonial Studies (Fall 1998), and Don Randall's earlier piece, 'Ethnography and the Hybrid Boy in Rudyard Kipling's "Kim.",
} 
turn of the last century. When class is put back into the picture, not only does Kim's status as white boy get murkier, but Kiplng's motives begin to seem more elaborate, suspect, and even poignant.

Before I go any further, let me foreground my approach to class, which I see as both a personal and political identity and a social structure that stretches across nations (and other geographical arrangements) and between them. It is my contention that class can best be understood as a diffuse category, created and apprehended not solely by means of a collective's economic or occupational circumstances, though these are hugely important notably in their relationship to political and social power, but also through such mediums as language, sexuality, experience, gender, choices or the lack of them, expectations and conditions in life, race, value systems, etc., in other words, through all the many formations embedded in cultural expression and constitution. Furthermore, while class can to a certain extent be theorized in abstraction, it is, like race, gender, and sexuality, fundamentally observable through the contexts in which it is made to mean something. My arguments are also premised on the belief that, as a result of the normative effect of middle-classness in most capitalist societies in the modern world, working-class lives, views, retaliations, and so on are either rendered invisible, because they are subsumed into middle-class assertions about what is right, normal, and wrong, or they are pathologized and so made dismissable.

In the middle-class dominated profession of literary studies, where a grouping that might be called 'working-class literature' has yet to be begotten, though canons of women's literature, South Asian literature, gay literature, African literature have been and continue to be amassed (to identify only a few of our many areas of specialization), we clearly collude in this naturalization of the middle class-and this in spite of the decades-long presence (albeit a contained one) of Marxist theory in our departments, the theory that is supposed to deal with class. Obviously, Marxist understandings, by themselves, aren't enough to provoke a full and thorough study of working-class writing, though they have been useful tools in analyses of middle-class imperatives. To remove the blind-spot about class from our shared field of vision, insights from other theoretical schools are needed too-from, for example, feminism, postcolonialism, and queer theory, all of which have greatly complicated commonly accepted notions of identity (as gendered, national, racial, and sexual for instance) at the same time that they have recognized the 
power, of dominant identities in particular, to regulate and thus to shape some realities. What I am promoting in this essay is a knowledge of class as some strands of Marxism see it-a structure brought about by the inescapable discord between authority and resistanceshot through with interrogations from these other kinds of theories. And I'm suggesting too the importance of a scholarship about class that is committed to the unearthing of working-class histories and writings and of the middle-class discourses that buried them and continue to do so.

In literary and historical scholarship about colonial India, while some of the working classes of the Indian population have won the attention of the Subaltern Studies collective and of a number of Marxist and nationalist historians over the years, the white and Eurasian working classes are among the least noticed of groups. Because they were racially affiliated with the whites who ruled India their experiences, opinions, practices, and values are usually confused with those of the elites, and, consequently, they disappear beneath the weight of British imperialism. When they do occasionally emerge into the mainstream and official historical or literary record, with few exceptions they appear as the scapegoats for white guilt about imperialist racism, as sexual predators, or as colourful but historically irrelevant and pitiable people. ${ }^{3}$ But their existence in colonial India was hardly as inconsequential or overwhelmingly malicious as most writings about this place and period make out. In the white and Eurasian working classes could be found not only the men who staffed the imperial railways and telegraphs, who served in the British army and in many of the lower rungs of the East India Company, and who worked as actual servants to white families and army officers, but the women who married these men and themselves became servants, or hairdressers, shop-assistants, prostitutes, mid-

\footnotetext{
3 There are simply so many examples of this kind of representation of poor whites and Eurasians in the literature and history that came out of the Raj that to name any of them here would be useless. But let me list some exceptions; what follows is a selection of those few works of scholarship that notice these groups of people in something other than stereotypical ways: David Arnold's two articles, 'European Orphans and Vagrants in India in the Nineteenth Century' and 'White Colonization and Labour in Nineteenth-Century India,' Race, Sex and Class under the Raj by Kenneth Ballhatchet, Christopher Hawes's Poor Relations: The Making of a Eurasian Community in British India I773-I833, Laura Gbah Bear's 'Miscegenations of Modernity: Constructing European Respectability and Race in the Indian Railway Colony, 1857-1931,' and Peter Stanley's White Mutiny: British Military Culture in India, I 8251875 .
} 
wives, and teachers. By the end of the nineteenth century almost half of the 150 ,ooo or so whites in India came from the working classes, and the Eurasian population (or Anglo-Indians, as they elected to call themselves in 1911) comprised about a hundred thousand more. ${ }^{4}$ In terms of their numbers alone, these were significant communities; what makes them even more worthy of our interest is their ambivalent and frequently wayward relationship to white imperialist power, a relationship rendered as tenuous as it was by the combined politics of class and racial difference.

In India during the centuries of the British Empire the drive to determine a person's race was an elemental one, for the simple reason that it was linked to the conservation and management of the imperialist enterprise as well as of the economic, communal, and linguistic hierarchies in that multifarious society. The privileges granted to those who could demonstrate whiteness (and not every apparently white person was required to do so) were, though various, still significant. And on the other side of the created divide, certain kinds of Indiannesses depended on claims of a racial purity not tainted by any outside blood lines such as those associated with whiteness, and I'm thinking here of upper-caste Hindu, all Parsee, and some upper-class Muslim ancestor-based identities. Given the importance of racial constitution to so many public arenas in this society, it's only to be expected that this issue would be of great general concern and would therefore emerge frequently in diverse forums. And so we see discussions of racial difference in official state discourse, in creative literature, in nationalist texts, and in academic ones throughout the period that saw the British in power in India, and these discussions invariably contain the usual unarticulated assumptions about the biological basis of race. But what leads us to suspect that, underneath this seemingly confident certainty, British and Indian people were troubled by the possibility that race was a constructed and not a biological truth is, first, the fact that there was any discussion at all about an ostensibly irrefutable reality and, second, the perpetual presence of contradiction and illogic in individual authors' commentaries and in the discourse as a whole. That racial difference existed was an argument that had to be made and then made again and again and again, made in fact endlessly and everywhere, stated boldly and arrogantly, in an attempt to repress

\footnotetext{
4 These numbers come from Arnold's 'European Orphans and Vagrants in India in the Nineteenth Century,' 104, and Hawkes's book, Poor Relations, 171.
} 
the sneaking suspicion that lay curled up in the argument's inconsistencies and in the frenzy of its articulation, the suspicion that the Indians and the British weren't the racial opposites they thought they were and that their political and cultural narratives needed them to be.

Race in colonial India, then, was a hugely contentious category, and it was contentious in a particularly heightened way for elite-class perceivers of both geographically-identified camps. More so than the non-elites, these privileged classes were distinctly advantaged by the Orientalist discursive tradition, a tradition that posited the ontological reality of racial purity as one of its foundational axioms. Within an Orientalist world view, as opposed to a liberal imperialist one ${ }^{5}$ the English and the Indians were, as collectives and individuals, diametrically different, with the English being superior at some things (material pursuits, historical activity, rationality) and the Indians proficient at their opposite others (spiritual pursuits, mythic constructions, emotionality). Because it was an imperialist discourse, however, it exalted those things associated with the colonizer, and of course it ultimately positioned the colonizer as the natural ruler of the colonized. Still, it nevertheless assigned a place of value to the Indian as well as to the English. And it was this admittedly contained valuing of the Indian that made some Orientalist views useful to certain Indian political programs. As scholars have documented, much of the mainstream Indian nationalist movement called on Orientalism for some of its assumptions about race, asserting in its turn a racial binary with the English at one end and the Indians at another, but inverting the Orientalist arrangement and declaring the superiority of the Indian. ${ }^{6}$

My point in offering you this brief synopsis of these intricate theories about the workings of English Orientalism and Indian Nationalism is that in both of these mutually-constructing discourses full

\footnotetext{
${ }^{5}$ Edward Said's Orientalism offers the best-known argument concerning the existence of Orientalism as an approach that structured the way the white rulers conceived of their colonies, but an earlier text, The Illusion of Permanence by Francis Hutchins, also contains a fine explanation of this brand of imperialism. For a discussion of liberal imperialism, see the third chapter in my Whose India?

${ }^{6}$ More detailed accounts of this use of Orientalist assumptions in the rhetorics of various Indian nationalisms can be found in Uma Chakravarti's 'Whatever Happened to the Vedic Dasi? Orientalism, Nationalism and a Script for the Past,' Romila Thapar's 'Imagined Religious Communities? Ancient History and the Modern Search for a Hindu Identity,' and Partha Chatterjee's Nationalist Thought and the Colonial World.
} 
racial authenticity, and hence the advantages associated with such legitimacy, resided solely at the extreme ends of the binary. Only those groups whose whiteness or Indianness was above question could be seen to possess absolutely the racial virtues attached to each position. And only cultural, political, social, and economic power, in other words class power, could secure a place beyond question. Those groups whose hold on such power was either feeble or non-existentin colonial India these would be the Indian depressed classes, including the Hindu lower castes and untouchables, the Christian or Muslim poor, the tribal peoples, the white working classes, and the Eurasians or Anglo-Indians-would often figure as subjects of eliteclass discussions about racial contamination and degeneration, discussions which kept their racial status open to debate. Consequently, racial flexibility came to be seen as a characteristic of people who belonged to non-elite classes. Depending on the context and the perspective, this flexibility could work either as a blessing or a curse, assuring them some kind of emotional, economic, legal, or political benefit or removing them entirely from the purview of power. The people of these working classes, however, had little control over the outcome of the racial flexibility accorded them by the elites. Different emphases in the policies of the British Raj or in the focus of the Nationalist agenda produced different historical situations for these groups. What all this points to theoretically is that in the India of the British Empire race cannot be understood outside of the constructive might of class.

The feasibility of this argument can be demonstrated best in a reading of a text as torn in its allegiances as Kipling's Kim. With its affectionate portrait of a working-class white boy, its thoroughly middle-class white author, and its tormented Orientalist approach to racial difference, this novel delivered to its first readers, and later to us, a colonial India in which the dominant rules about class and race are safely upheld at the same time that they are fantastically allowed to bend in the service of love and friendship. My own starting point for re-reading Kim in the light of this kind of attentiveness to class is Edward Said's analysis, which appeared first in the introduction to Penguin's 1987 edition of Kim and later as a chapter in his 1993 book Culture and Imperialism. I like to think of my argument as adjacent rather than opposed to Said's famous interpretation, adjacent as in lying near or in some kind of neighbourly relation to it. Because, although I would contend that Said applies an Orientalist paradigm to the novel that reduces its complexity to the conventional 
colonial and postcolonial story about India versus Britain, and so misses out on the class difference it also encodes, I'm absolutely convinced that he is right when he observes that the novel is an inscription of Kipling's investments in an Orientalist mode of imperialism. I don't believe, however, that Orientalism, as it is understood these days, is subtle enough to accommodate Kipling's work completely.

Prior to Said's book, Orientalism had been generally understood as an academic tradition or a collection of texts about the Orient composed over two centuries by Western scholars. He dramatically revised this earlier definition when he suggested in 1978 that Orientalism is also a huge system of knowledge that functions as a way to power for the West. As a knowledge, it is driven by a 'will or intention to understand ... [and] in some cases to control, manipulate, even to incorporate, what is a manifestly different (or alternative and novel) world ...'(12). An amazingly comprehensive discourse that touches virtually every academic discipline, Orientalism, Said insists, is thoroughly complicit with imperialist and neoimperialist politics. He goes on in the book to define the 'essence of Orientalism' as 'the ineradicable distinction between Western superiority and Oriental inferiority' (42).

When Said uses this theory in his reading of Kim, the result is a text that enshrines a polarity between the Occident and the Orient, between white and brown, between Kim and every Indian character:

The division between white and non-white, in India and elsewhere, was absolute, and is alluded to throughout Kim as well as the rest of Kipling's work; a Sahib is a Sahib, and no amount of friendship or camaraderie can change the rudiments of racial difference. Kipling would no more have questioned that difference, and the right of the white European to rule, than he would have argued with the Himalayas. (Culture 134-5)

Sometimes, we have to argue with the Himalayas: it seems to me that Said's interpretation of Kim is a prime example of the hazards involved in the wholesale application of a generalizing theory to a particular novel. Said's Orientalism can accommodate Kipling's story only part of the way, after which it begins to operate like a snowstorm: as an attempt to elucidate the workings of racial power in this text, it covers up some of the interesting, elusive, and resistant bits that have to do with class. Without losing sight of the fact that Kipling was an imperialist Orientalist, which means that his work was dedicated to the continuation of British rule in India, we can still find in Kim an even more complex vision of imperialism, one 
that, at least for his working-class protagonist, has a certain emancipatory though still treacherous potential. And in this vision of imperialism, a vision that Kipling tries to catch from the perspective of Kim's working-classness, a Sahib is not always a Sahib and not all Europeans have an equal right to rule.

It is significant that Said does not and cannot use Orientalism to account for Kim's class. Nor is the theory entirely adequate as the explanation for why Kim is sometimes designated an Oriental, possessing so-called Oriental traits like the ability to sleep while a train rushes by and a gift for lying convincingly, and at other times is called a Sahib or white man, for instance, when he demonstrates his fear of snakes. I think that Kipling was trying here to come to terms with an ideal of cultural combination, and, furthermore, that given British imperialism's strong connections to the middle class, the only figure on whom he could attempt such an amalgamation would have to be a member of the white working classes.

Decades and decades of literary scholars have noticed that, of all his characters, Kim is Kipling's ideal, that he is the focus of much of Kipling's desire for India, that he is, certainly, the stuff of Kipling's fantasies. He gets to live his creator's dream life, one that is free of middle-class conventions, full of adventure and intrigue, and plays itself out in India, the land that Kipling loved and to which he could never, in his own life, quite belong. I fully agree with this view. Where we have to be careful, however, is in confusing Kipling's ideal, Kim, with Kipling himself. Unlike the character of Fielding in E. M. Forster's A Passage to India, who, as an ideal figure, is very much like his creator in that both author and protagonist are male, white, middle-class, sympathetic to middle-class Indians, and liberal thinkers, Kim shares with Kipling ony whiteness, maleness, and a love of India. In the context of Kipling's private and political philosophies, which were conservative in their class and race consciousness, and in the context of British India's highly-stratified colonial culture, Kim's Irishness and working-classness are subjectivities far removed from Kipling's own reality, and, consequently, they represent drastic departures from the world that Kipling himself inhabited. Moreover, they are subjectivities about which Kipling was profoundly ambivalent.

And there is this other point to remember: choosing to make Kim working class wasn't an obvious choice for him. If he simply wanted to remove a child from middle-class restrictions (which many critics seem to believe was his reason for making Kim poor), he could easily 
have drawn on a popular Anglo-Indian myth about the white, middleclass English boy lost during the Mutiny and raised as a native. That he made Kim the orphaned son of Irish Catholics, one of whom was a nursemaid in the employ of an English Colonel and the other a colour-sergeant with the Mavericks, an imaginary Irish regiment of the British Army, which means that Kim is by birth a member of a group Kipling calls 'poor whites ... in India' $\left(5^{\mathrm{O}}\right)$, suggests deliberation to me.

To anyone who knows something of the white working classes of colonial India, the circumstances of Kim's life and those of his parents seem designed to repeatedly affirm his placement within that class and among those people: his mother was a servant, his father a soldier, who, quite typically for British soldiers once their term of service was over, 'took a post on the Sind, Punjab, and Delhi Railway, and his Regiment went home without him' (49). We are given even greater detail when we are told that Kim's father was 'gang foreman on the Ferozepore line' (50), which was a subordinate supervisory position on the railways, usually reserved for Eurasians (people of Indian descent on their mother's side and European on their father's) or domiciled Europeans (Europeans, mostly working class, who remained in India for the duration of their lives). The connections between domiciled Europeans, like Kim and his parents, and Eurasians were not only official in nature - that is, the government of India frequently insisted on lumping 'poor whites' and Anglo-Indians together when creating certain racist and classist policies-but social and cultural as well; by the end of the 19oos, a number of railway colonies, which had sprung up throughout India, were home to both communities. Not surprisingly, there was a good deal of social interaction and intermarriage between them too: indeed so much so that, according to David Arnold, 'the domiciled European railwaymen and Eurasians by the 1920 s were fusing into a single community' ('White Colonization' 153).

The complications of the historical relationship between the white working classes and the Eurasians in India find expression in the life and character of Kim himself. His links to the Eurasian community are alternately forged and then broken or denied. On the first page of the novel, after his racial pedigree is established-he is white, though 'of the very poorest' - we learn that his foster mother is Eurasian; the narrator chooses to describe her as the 'half-caste woman who looked after him' (49). So seemingly inconsequential is this woman that she disappears from the story after the first three pages. 
Furthermore, neither we nor Kim are expected to notice her absence. As an opium smoker who gave Kim's father a taste for the drug, and so led him to his pathetic death, as a dishonest and very poor woman who 'pretends' to run a second-hand furniture shop (49), as a stupid or perhaps intoxicated woman who can't properly remember Kim's father's statements regarding Kim's entitlements as the son of a soldier and a mason, she is negligible in this text. And yet this is the woman who, for some reason the novel does not disclose, looked after someone else's child for years after his father's death, even going so far as to pass herself off as his mother's sister to keep the missionaries from taking Kim away from her and putting him in an orphanage $\left(49^{-} 5^{\circ}\right)$. Kim's foster mother is expendable in Kipling's novel not because she has Indian blood, since a number of the central characters are Indian and wholly admirable, nor necessarily because she is of mixed descent, for, later on when praising the 'country born and bred boy[s]' (171) who are Kim's fellow students at the elite St Xavier's School, the narrator writes respectfully of the 'cadets of the old Eurasian houses that have taken strong root in Dhurrumtollah-Pereiras, De Souzas, and D'Silvas. Their parents could well have educated them in England, but they loved the school that had served their own youth ...' (171-2). The respect implicit in this passage is accorded these Eurasian families as the result of their long history in India, ${ }^{7}$ their tradition, and their upper middleclassness. Kim's foster mother is expendable because she is 'halfcaste,' which, in this novel, means she is Eurasian as well as working class.

Although a generous and even loving novel in some of its portraits of Indians (Mahbub Ali, the lama, Hurree Babu, the woman of Kulu) and middle-class ruling whites (Colonel Creighton, Lurgan Sahib, and Father Victor), Kim falters in its generosity when it comes to 'half-castes' and 'poor whites.' With Kim as the one consistent exception, the novel reserves a special kind of contempt for members of these two working-class communities, and it often makes Kim a cospokesman, along with the narrator, of this contempt. The white drummer boy who is placed in charge of Kim after his capture by his father's regiment is a thoroughly repulsive character-vulgarly racist, lethargically stupid, and periodically violent. The narrator tells us that Kim 'loathed him from the soles of his boots to his

\footnotetext{
${ }^{7}$ The names indicate descent from the Portuguese who were among the first European imperialists in India.
} 
cap-ribbons' (148), which is surely something of an unfriendly reaction for a boy who regards himself and is regarded by others as the 'Little Friend of all the World.' That the drummer boy is not meant to be read as an individual or an exception but is instead one component of a generalized class portrait is evident in the universal comments the narrator easily falls into when referring to people from the working classes-for instance, in the statement about the insipid, single-word talk of drummer boys' (172) and in the overall descriptions of the settings in India inhabited by the white working class: the camp and the barracks. The barracks is a bleak place for Kim, for the schoolmaster who is too cynical even to try to teach Kim to read, and for the other boys. And the camp is where Kim is caught and tethered, so it too contributes to the aura of imprisonment and stunted growth that surrounds these working-class sites in the novel. In fact, Kipling only seems to approve of this white community once war is declared and it lives up to its 'reputation for liveliness' (146), suggesting that working-class white people are at their best when anticipating opportunities for violence.

The contradiction in character that occurs when the Little Friend of all the World finds himself hating a boy more like himself than the novel wants us to know has yet another expression, this time a racial one. Kim, the supreme democrat whom we see repeatedly flirting with Indian prostitutes and relying on their kindness and goodwill in his travels, speaks with anomalous distaste of low-caste Indian women. When Colonel Creighton counsels him not to 'despise the black men' as some of the students at St Xavier's do, Kim immediately assumes that he knows who these racist students are: " "Their mothers were bazar-women," said Kim. He knew well there is no hatred like that of the half-caste for his brother-in-law' (167). This uncharacteristic snobbishness comes up again when Mahbub Ali innocently attempts to describe the boys of St Xaviers as 'Sahibs.' Kim's response is as vehement as before: “"Not all!" Kim cut in with a snort. "Their eyes are blued and their nails are blackened with low-caste blood, many of them. Sons of mehteranees-brothers-in-law to the bhungi [sweeper]"' (192). Mehteranees, we are told in Said's note to the Penguin edition, means princesses and is 'an ironic courtesy title for women cleaners' (354). What is significant here is that it's not so much Indianness that taints the blood of some of the privileged white men's sons and grandsons who attend St Xavier's. It's working-class Indianness. The mehteranees and the 'bazar-women' are distasteful to Kim and to the narrator because, socially, econom- 
ically, occupationally, they are at the bottom of the Indian caste and class system. They have three strikes against them: they are not white, not male, and not ruling class and so are far removed from all the positions of privilege available in colonial India. Moreover, they represent a threat to established English interests in that, for Kipling and Kim and the narrator, they symbolize the possibility of the racial and the class contamination of elite male English blood. Such contamination is dangerous because it undermines the internal cohesion of the white, middle-class colony. Through their mixedrace, mixed-class children, low caste women (as well as 'half caste' women) blur the lines between comfortably classed and raced communities. They are, consequently, the sites where the instability, where the sheer make-believe of these borders becomes apparent.

But, for Kipling, these make-believe borders are more than real; they are eternal and natural, though, strangely enough, they still have to be guarded. And that is partly what the novel is doing. Kipling knew that many of his turn-of-the-century readers would associate Kim, the 'poor white', with the Eurasian people in India because, as I've already mentioned, not only did the government and other elite-class white authorities constantly link these two communities but so had historical circumstances. By raising the image of working-class Eurasians first through the mention of Kim's foster mother and then through the spectre of the low-caste woman who is thought to be the progenitor of all working-class Eurasians and, subsequently, demonstrating Kim's distance from this image (his foster mother is not his real mother and he has only contempt for the mehteranees who are supposed to be the creators of certain Eurasian children), Kim assures those readers that Kim is fully white: the borders that protect white rule haven't been breeched.

Readers also don't have to worry that Kim's own working-classness will infiltrate elite-class prerogatives and thus disturb the status quo in British India, since the novel has already confirmed-through the depictions of the drummer boy, the barracks, and the camp-Kim's emotional distance and cultural difference from this community. We are supposed to assume that Kim's remoteness from them prevents him from exhibiting those reputed collective tendencies that the ruling classes in India so despised in the white working classes, some of which we see in Kim-their 'liveliness' (Kipling's code word for drunkenness, I suspect), their violence, and their propensity for entering into marriages or other sexual liaisons with Eurasians or low-caste Indian woman. But though distant and different from the 
people of this community, Kim is not, therefore, middle class. $\mathrm{He}$ has neither the connections nor the appropriate training. (It's doubtful that he even has the accent.) Ultimately, for those early readers of the novel, Kim is an unusual but safe kind of white working-class person because he has none of the vices the rulers associated with the working classes, none of the emotional ties that might allow those vices to arise in the future or that might make his actions unpredictable, and no claim to middle-class status at all.

In Kim Kipling has taken his protagonist away from what the ruling class whites believed were degrading influences: working-class parents, working-class communities, and working-class places of residence. His decision to construct his hero in this way is hardly a coincidence. Nor is it original. He was, in fact, only doing what white administrators all over India tried to do to the children of European soldiers, sailors, servants, and railway workers, whether these children were orphaned or not. In the early decades of the nineteenth century, orphanages and charity schools for the children of "poor whites' and Eurasians sprang up initially in or near the great imperial cities of the plains, Calcutta, Madras, and Bombay, and later in virtually every town, cantonment, and hill station. And, though ostensibly these institutions were meant to provide an education and sometimes a home for the destitute children of the Raj, the children of the East India Company's army personnel and civil employees, they also functioned as the means through which the rulers managed what they viewed as an assault on their prestige in India. We are encouraged in the novel to think of Kim as an exotic rarity, a white boy who grows up in the bazaars of India and who is, as a result, closer to and more knowledgeable about the various Indian cultures than most white boys could ever hope to be. But the historical evidence suggests that this situation was much more common than the middle and upper-class white community liked to believe. It was precisely because there were too many white and Eurasian orphans roaming Indian streets and growing up around Indian bazaars that the civil and military administration as well as the missionary societies took control of these children's lives. And even as late as 1860, in a minute that was to shape the European educational policy for the next seventy years, the Viceroy, Lord Canning, lamented the existence of these children-some of whom were orphans while others had parents still living-and warned that if the government of India did not take prompt measures to address the problem, 'we shall soon find ourselves embarrassed in all large towns and stations 
with a floating population of Indianized English, loosely brought up, and exhibiting most of the worst qualities of both races ...' (qtd. in Arnold, 'Orphans and Vagrants' 110).

The embarrassment that these children represented to the white elite stemmed first from their poverty. The Raj saw itself as a middle-class enclave, and the presence of poor children of European descent invalidated that carefully-constructed impression. Furthermore, the middle-class rulers, believing unquestionably in their own worthiness, wanted to 'preserve India as the personal estate of the white "aristocracy", to use Arnold's words ('White Colonization' 148), and, therefore, they resented any encroachment on that preserve from these children or their parents. The second reason these children were a source of embarrassment for the administrators of India was because they were products of working-class culture, and the highly class-conscious white elite saw this culture as a degraded and offensive version of its own. The white working classes demeaned them in the eyes of their Indian subjects and hence undermined British imperial authority, which was founded, they insisted, on the respect and fear that Indians felt for their conquerors. 'Europeans were meant to be visible only as a super-race,' Arnold writes, 'never aged and infirm, never scantily clad, uneducated orphans playing in an Indian gutter' ('Orphans and Vagrants' 114). For the white rulers, then, the existence of 'poor whites' in India constituted more than a nuisance or a disgrace or an added responsibility: in their everyday lives and persons, they were dangerous.

Their answer to the 'problem' of the white working-class population was institutionalization and deportation. Adult white male vagrants were sent to workhouses and occasionally deported, their female counterparts were almost always deported (because administrators feared that their poverty would lead them to prostitution), and the orphaned children of both the Eurasian and white workingclass communities were placed in orphanages. The point of all the administration surrounding the working classes was to exclude them from power and to render them invisible. If they could not be made to disappear from society entirely, they had to be transformed into so-called 'useful' appendages to white rule, useful, of course, not necessarily to themselves or to their communities but to the elites who used them to staff their armies and navies, to clean their houses, to care for their children, to dress their hair. Orphanages accomplished this by offering their charges only the kind of education that would enable them to re-enter society at precisely the social level 
from which they were removed. One of the rules of the European Female Orphan Asylum in Calcutta expresses this sentiment exactly: 'The[ir] education ... is to be plain and suitable to their situation and prospects in life: such as shall tend to make them good and useful members of society, whether they become housekeepers, or servants' (qtd. in Lushington lxxviii). Girls and boys were generally both taught basic reading, writing, and 'cyphering' skills as well as Anglican catechism (Lushington 261), but while the girls learned to knit, to do needlework, and to keep house, the boys often received some form of military training. At the Lower Orphan School and the Female Orphan Asylum in Calcutta, female students also contributed to the funds of their respective institutions by doing embroidery work, dressmaking, and knitting for middle-class clients outside the school (see Lushington 262 and lxxviii), which suggests to me that what these girls were receiving was not entirely charity, though the state and missionary organizations had to couch their reclamation projects in these terms in order to justify the amount of control they took away from these children and from their families and communities. It is also significant that, during the time they remained in the orphanages, any contact between them and their friends or relatives was actively discouraged. And when these children reached their teenage years, they were sent back into society, the boys usually to take up the occupations of their fathers, becoming drummers, fifers, and soldiers in British regiments, while the girls were placed as domestic servants in richer European homes, or married off to British soldiers, a few receiving enough academic education to become teachers, most often in elementary schools for Indian children.

It is a particularly telling fact about these orphanages that children didn't necessarily have to be orphaned to be placed in them. Many children of soldiers were removed from their parents' homes after their third or fourth year of age and sent to the Lower Orphan School for the duration of their education. The children of Artillery men at Dum-Dum, where a Regimental School had been established, were exceptions to this rule. In his 1824 book on the charitable institutions of Calcutta, Charles Lushington states that 'Fathers of sober and respectable character' who were stationed in Dum-Dum were occasionally permitted to keep their children at home until their seventh or eighth year. But he adds that the 'Commandant is ... to revoke this indulgence, whenever the conduct of the parents shews them undeserving of it's [sic] continuance, or a proper regard to the welfare of the children, renders their removal from Canton- 
ments expedient' (26o). For the white working classes of colonial India, the right to raise their own children beyond the age of four was an 'indulgence' granted by the white authorities if they judged working-class fathers 'respectable' enough to care for their children properly, meaning according to middle-class notions of child-rearing. As Arnold argues, one of the purposes behind the creation of orphanages for poor European children was 'to rescue them from the "corrupting" influences of the environment in which they were found' (109-10). Among these 'corrupting influences' were the barracks, the Indian bazaar, and the overall degradation that middle-class rulers believed characterized the white working-class home.

Clearly, then, white orphans in colonial India were the recipients of a form of state-sanctioned (and perhaps even state-controlled) middle-class charity that condemned their families as ignorant and incapable of virtue and that allowed them to join public life, a white middle-class preserve, only through carefully-regulated routes, as servants, soldiers and soldiers' wives, teachers of Indian children, and so on. These children, like Kim himself, enter imperialist discourse only to be managed by it, only to be made less unpredictable, less threatening, and more useful to the white elites who take it upon themselves to intervene in their lives.

It is exactly this kind of intervention that Kim spends most of his time trying to evade in Kipling's novel. The narrator at first celebrates Kim's freedom from the institutions that would have ruined him: 'As he reached the years of indiscretion, he learned to avoid missionaries and white men of serious aspect who asked who he was, and what he did. For Kim did nothing with an immense success ... but missionaries and secretaries of charitable societies could not see the beauty of it' $\left(5^{\mathrm{O}-1}\right)$. When he is finally caught and, by his remarkable good fortune, manages to avoid being sent to either the military asylum at Sanawar or the Masonic Lodge in the hills but is shipped off, mostly unwillingly, to St Xavier's instead, the narrator's tone becomes much more compromising. Some readers today might be tempted to believe that this unwanted intervention of the colonial state in Kim's life, which results in his years of education at the somewhat prestigious St Xavier's School, transforms him into a middle-class white man. St Xavier's caters to the middle-class white and Eurasian communities and, therefore, the novel seems to assure us, can transform Kim into a proper Sahib. The process of this transformation is the school's primary objective, as one of St Xavier's maxims suggests, 'One must never forget that one is a Sahib, and 
that some day, when examinations are passed, one will command natives' (173). But Kim, we know, will not become the Sahib the school seems designed to turn him into, for the novel never lets us believe that he will ever be in a position to rule in India. Nowhere is it suggested that he will go on, for instance, to 'command natives.' As the full grown, fully initiated secret service agent who emerges from sickness and sleep at the end of the story, Kim is the political equal of men like Mahbub Ali, Hurree Babu, and E23, and this is, of course, what he has aspired to be. What he emphatically is not is an equal to Colonel Creighton, the administrator of the Secret Service and, clearly enough from his title, an officer in the British Army. Such a career leap for Kim would have been regarded as absurd by those first readers of Kipling's text, who would have known that, in these terms at least, India was not so different from England and that very little social mobility existed for white working-class people. Even an education such as Kim's couldn't gain him entrance to the elite occupational circles of the British Raj, the upper reaches of Indian Civil Service and the Army. Indeed, Kim's working-classness effectively bars him from becoming an officer in the army or an administrator of any kind in colonial India. There were simply too many obstacles to working-class people, obstacles designed specifically to keep them out of elite circles and to ensure that the highestpaying and most secure jobs were preserved for male members of the middle and upper classes.

Full Sahibhood in British India and in this novel requires masculinity, whiteness, and the authority conferred by middle- or upperclassness. While Kim possesses the first two, at no point does he acquire or is he accorded the latter. Said's comment that 'a Sahib is a Sahib' is only true, therefore, if the requirements for this identity are whiteness and maleness. When we make the working classes of the resident white population in British India visible, we realize that a Sahib is sometimes a Sahib and sometimes not, depending entirely on the context in which the title appears. Kim's contradictory statements about his identity_-... I am a Sahib' (166), 'I am not a Sahib ...' (183), 'I shall soon be altogether a Sahib' (178), 'I do not want to be a Sahib ...' (155) - are perfectly sensible given the historical predicament that conferred sahibhood on white working-class men in India when whiteness and maleness were the determining privileges but then denied this status in those circumstances replete with the play of class structures. Kim is only a Sahib when it is convenient for Kipling to make him so, when, for example, Kim's status as white 
contributes to the racial authority of the ruling white elites. Otherwise, he is detained in that nebulous racial space between racial purities, between Englishness and Indianness. And it is exactly his working-classness that puts him there.

Obviously, there were serious unpleasant possibilities lurking around the creation of a working-class white character, many of which possibilities this novel reveals, and still Kipling chose to make Kim working class and, further, to imagine him engaged in a fundamentally hopeful and affirmative story. This character, whose class would have made him seem detestable, tawdry, and limited in the eyes of the middle-class whites who constituted that part of Kipling's earliest audience mostly likely to have bought his book, is nevertheless imagined in buoyant and optimistic terms. The twist is that, in spite of the restricted conditions that historically circumscribed the white working classes in India, only these classes held, for Kipling, the potential to be liberated from all the things that kept Kipling himself contained, that kept him from inhabiting India as fully as he wanted to. I'm going to approach this construction of Kim as 'poor white' and yet rich in freedom by way of one of Kipling's other working-class personalities-the speaker in 'Gunga Din'-because when Kim is placed in relation to him, a pattern emerges, which is a significant part of Kipling's treatment of working-classness as a subject position in British India.

'Gunga Din' is about a British soldier who, like so many of Kipling's working-class men, remembers his time in India with a mixture of intense affection and sadness. The poem tells us the story of this soldier who seems to have gone out to India with the quite understandable assumption that the people he would encounter there would be inferior to him in every way. I say 'quite understandable' because British imperialism encouraged white people in England, even the working classes, to see themselves as natural rulers. Once in India, the British soldier carries this assumption into action by asserting authority over the untouchable water carrier, by beating him and abusing him. But the circumstances of war, in which Gunga Din performs incredible acts of courage, even, finally, saving the speaker's life at the cost of his own, leads the British soldier to the vivid realization that, in spite of the promises of imperialism, the morally superior of the two is the untouchable water carrier. In the last lines of the poem the soldier's audience shifts; he no longer speaks to the young, inexperienced recruits who are his listeners at the beginning of the tale, but to the dead man himself, as if the 
magnitude of this revelation requires a face to face admission of his own inferiority:

Yes, Din! Din! Din!

You Lazarushian-leather Gunga Din!

Though I've belted you and flayed you,

By the livin' Gawd that made you,

You're a better man than I am, Gunga Din! (Barrack Room 26)

So, although the poor white speaker has been privileged by virtue of his whiteness in India, he is nevertheless able to recognize greater loyalty, courage, and morality when he sees it-importantly, these are all qualities associated with whiteness in standard Orientalist ideology.

What this speaker has in common with Kim is his willingness to concede, at least to some extent, the superiority of an Oriental person and his own position of dependency in relation to him. ${ }^{8} \mathrm{Kim}$ does this throughout the novel, when he touches the feet of his surrogate fathers, Mahbub Ali and the lama, for example, and when he cries in front of the lama because he feels that he's not been a good disciple. At this point the narrator tells us, 'Overborne by strain, fatigue, and the weight beyond his years, Kim broke down and sobbed at the lama's feet' (320). This is an act of submission to an Oriental by a white boy or man, hardly the conduct that befits a Sahib in India. But, as I've argued earlier, Kim's Sahibhood is shaky at best. Unlike Colonel Creighton, a true agent of the Raj, he occupies this racial and social category unevenly.

It is extraordinarily meaningful that in Kipling's poetry and prose about the East, white working-class people are the only characters and speakers who ever suggest that the East is equal to the Westeven that the East is better than the West. His British middle-class characters sometimes declare their respect and affection for particular Eastern traditions, knowledges, and people, but I have yet to find one who professes that the East, in some fundamental way, is equal or superior to the West. For Kipling, white working-classness seems to permit a certain subservience to India that is completely impossible for the British middle class who are the rulers of the country. Such behaviour, such confessions as those expressed by Kim and the

\footnotetext{
${ }^{8}$ I've recently discovered that I'm not the only scholar who has made this observation. In her wonderfully provocative reading of the original Barrack-Room Ballads, Ann Parry also argues that certain kinds of imperialist sentiment in Kipling's writings are class specific and that working-class speakers in his poems often align themselves with 'subject races of foreign parts' (48). See the chapter entitled 'Missis Victorier's Sons' in her 1992 book The Poetry of Rudyard Kipling: Rousing the Nation.
} 
British soldier can be made only by the working-class white people in the East because, being already low on the social and political hierarchy, they do not have as much to lose as the middle class. In Kipling's eyes, their poverty and their working-classness guarantees their freedom. It allows them to do what Kipling himself could never do: surrender to India. That they can surrender to India where the middle-class characters can't is the result, however, not only of Kipling's assumption that they had less access to the power implicit in white rule than their middle-class counterparts. Such surrendering can also be traced to an unexamined belief about the nature of working-class people.

Along with so many other middle-class authors who write about working-class lives, Kipling presumes that working-class cultures are deficient in relation to middle-class cultures, deficient as opposed to simply different. So working-class people are often constructed as deficient in decorum, in values, in tradition, and so forth. Indeed, what makes them working-class is the absence of middle-classness, however that might be constituted. That the working classes might have different structures of value, different senses of decorumrather than no values, no decorum, no money, no taste-is rarely conceded or explored in literature by middle-class authors. Undoubtedly, this translation of difference into deficiency has everything to do with the normative authority accorded middle-class perspectives, an authority which limits a middle-class author's ability to see beyond the boundaries of middle-class privilege. Occupying a class that has embraced the status of the normal and the universal, middle-class authors are frequently unable to imagine as anything but deficiency the differences in taste, values, traditions, perspectives that working-class cultures potentially possess. What this means is that those middle-class writers who create positive and romantic depictions of working-class lives, such as Kipling, are often engaged in fantastic projections. In Kipling's case, he projects his own desire to be free of British middle-class cultural restrictions onto his male working-class characters. Being free of middle-class restrictions, they are, he assumes, free of all restrictions. And, consequently, they can be what he, in his middle-class self, could not be, not at least without placing his class status in jeopardy: unconstrained by the power dynamics of British imperialism, they can be equals and, therefore, friends with Indian people, or so Kipling imagines.

But if, through the characters of his British soldiers, Kipling is content to demonstrate the possibilities of friendly alliances between British men and Indian people, in Kim he is striving after an even 
more permanent connection. Kim is not simply a friend to the Indian men and women he meets in his adventures; as the surrogate son of Mahbub Ali, the lama, and the woman from Kulu, he is family. The novel Kim is Kipling's one attempt to cross the racial boundary between the Indian and the British and envision an Indian identity for a white person. In his book on the psychological costs of colonialism, The Intimate Enemy, Ashis Nandy insists that Kipling himself, at some level of his race-tormented psyche, longed to be Indian, though this longing was doomed to remain unfulfilled because of the racist complex of British imperialism. To the point of self-destructiveness, Kipling struggled with a racial identity crisis. His 'dilemma,' Nandy argues, was that 'he could not be both Western and Indian: he could be either Western or Indian' (71). Unlike the westernized Indian who was free to embody both of his cultural influences, India and the West, because he was already subjugated (Hurree Chunder Mookerjee, the Bengali Babu in Kim, for example), Kipling and other white rulers were caught in an ideology they helped to produce. This was a way of thinking that forced on English people in India a debilitating definition of whiteness, which would not admit any acknowledgement of the medley of their identities. Nandy asserts that this choice between the West and India constituted the 'tragedy' of Kipling's life because it made him reject his 'under-socialized Indian self' (71). But Kipling could not embrace his Indianness since to do so would be to jeopardize the claim on which the British Empire was founded-the white man's superior ability to rule. Those white rulers who wished to maintain the Empire and hang on to the privileges it conferred on them had to identify exclusively with the West, and the cost of this choice was the repression of their Indian allegiances and connections.

But in terms of the sort of permanent relationship with India and Indians we see in Kim, white working-classness constituted a difference in colonial India. Given that many, many British working-class men married Indians and stayed in India the rest of their lives, thereby creating their descendants, the community racially distinguished as Eurasian, I suspect that not all white people in India were equally bound by the rules of the psychological game Nandy describes because not all white people had the same political investments in India. Not all of them were so privileged by white rule that they were prepared to reject their attachments to India and Indians. Certainly, in Kipling's writing, it was a distinctly working-class option not to have to make this choice. The working-class characters in his stories 
and poetry about India behave in ways that suggest that they are, therefore, products of Kipling's historical observation of actual working-class people and his own personal wish-fulfilment. As such, they are permitted the luxury of voicing their preference for India and of exploring those aspects of their own psyches that meet and match the Indians they encounter. Some of them, like Kim, even get to be Indian, undoubtedly because Kipling never could be.

If the novel Kim is nothing else, it is the record of a longing to be Indian. In it, a white boy gets to move among the people of India in a way that wasn't possible for Kipling. Through Kim, Kipling constructs a new kind of Indian, a white Indian, a cultural medley who alternately declares and denies that he is a Sahib and who expresses fully, sometimes in contradictions, all the sides of his multicultural self. This is the achievement of the book, that it imagines and demonstrates a relationship between Indians and whites that is founded not only on the oppressive racial hierarchy of British imperialism.

But let me remind you of an earlier comment in this essay about the emancipatory though still treacherous potential of this novel's portrait of the white working class in India. The treachery resides in Kim's displacement from power as a result of his working-class status, which makes him susceptible to middle-class insistences. Sara Suleri recognizes something of this insidiousness in the novel's construction of its protagonist. Kim, she says, is 'an imperial casualty of more tragic proportions than he is usually granted' (116). Coerced into receiving a colonial education through the combined efforts of the unwitting lama and Colonel Creighton, Kim is transformed into what Suleri describes as a 'Macaulayan interpreter' (127). While the pre-educated Kim is a culturally fluent child who reads India and Indian people in order to access cultural knowledge, after his years at St Xavier's School, his fluency is constrained, limited only to the retrieval of bureaucratically-useful information. Suleri writes:

It is not as though Kim stands outside the colonial system called the Great Game and ... has the luxury of choosing whether or not to play it; instead, Kim is the Game, and finally is unable to separate it from the parameters of his own history. Kim's collaboration is therefore emblematic of ... the terrifying absence of choice in the operations of colonialism. (116)

The question that Suleri does not answer, however, is why Kim? What makes him susceptible to this coercion? There are two things: first, his status as a white working-class individual, and, second, his isolation from that class and the history of that class in India. It is precisely Kipling's construction of Kim as a working-class white who 
is fully alienated from his class community that allows him to represent Kim as not ultimately belonging to any group, which is exactly the quality that enables him to traverse so many different identities and therefore makes him a good spy and therefore useful to the Empire. But such alienation produces a debilitating cultural and class dispossession. Kim's race identification is precarious at best, and his class allegiance is non-existent. By removing from him any connection to the white working classes into which he was born, Kipling leaves him in a position of stark political isolation. Thus the 'terrifying absence of choice' that Suleri quite astutely discerns in Kim's collaboration with the Raj is the result of a working-classness detached from a solidarity that functioned historically as the means through which the white working classes forged a place for themselves in colonial India, a place that was separate from the ruling white middle-class though, at times, implicated in its racist imperialism. Kipling takes from Kim his class history and compensates him with a political placement on the edges of imperial power. Though the white working classes in India occupied these edges, Kim's tragedy is that his placement there is marked by its singularity. At the end of the novel there is no collective to which Kim belongs. There is, for him, only an exploited and almost classless space, an individual's space, which ensures his continued compliance with the imperialist project and the white middle class set in authority over him.

\section{Works cited}

Arnold, David. 'European Orphans and Vagrants in India in the Nineteenth Century.' The Journal of Imperial and Commonwealth History 7.2 (January 1979): 10427.

. 'White Colonization and Labour in Nineteenth-Century India.' The Journal of Imperial and Commonwealth History 11.2 (January 1983): 133-58.

Ballhatchet, Kenneth. Race, Sex and Class under the Raj: Imperial Attitudes and Policies and their Critics, I793-1905. London: Weidenfeld and Nicolson, 1980.

Bear, Laura Gbah. 'Miscegenations of Modernity: Constructing European Respectability and Race in the Indian Railway Colony, 1857-1931.' Women's History Review 3.4 (1994): 531-48. 17 Aug. $2000<$ http://www.triangle.co.uk/whr/ index/htm>

Bucher, Christine. 'Envisioning the Imperial Nation in Kipling's Kim.' Journal of Commonwealth and Postcolonial Studies 5.2 (Fall 1998): 7-17.

Chakravarti, Uma. 'Whatever Happened to the Vedic Dasi? Orientalism, Nationalism and a Script for the Past.' Recasting Women: Essays in Colonial History. Eds. Kumkum Sangari and Sudesh Vaid. New Delhi: kali for women, 1989. 2789 . 
Chatterjee, Partha. Nationalist Thought and the Colonial World: A Derivative Discourse? London and Delhi: Zed Books and Oxford UP, 1986.

Craft, Brigette Wilds. 'Apprentice to Empire, or, "What is Kim?", Journal of Commonwealth and Postcolonial Studies 5.2 (Fall 1998): 18-35.

Hawes, Christopher. Poor Relations: The Making of a Eurasian Community in British India I773-I 833. Richmond: Curzon, 1996.

Hubel, Teresa. Whose India? The Independence Struggle in British and Indian Fiction and History. Durham and London: Duke UP, 1996.

—. 'Tommy Atkins in India: Class Conflict and the British Raj.' Kunapipi. 22.1 (2000): $95^{-105}$.

Hutchins, Francis G. The Illusion of Permanence: British Imperialism in India. Princeton: Princeton UP, 1967.

Jussawalla, Feroza. '(Re)reading Kim: Defining Kipling's Masterpiece as Postcolonial.' Journal of Commonwealth and Postcolonial Studies 5.2 (Fall 1998): $112-$ 30.

Kipling, Rudyard. Barrack-room Ballads. 1892. Oxford and New York: Woodstock, 1993 .

Kim. 1901. London: Penguin, 1987.

Lushington, Charles. The History, Design, and Present State of the Religious, Benevolent and Charitable Institutions, Founded by the British in Calcutta and its Vicinity. Calcutta, 1824 .

McClintock, Anne. Imperial Leather: Race, Gender, and Sexuality in the Colonial Contest. New York and London: Routledge, 1995.

Nandy, Ashis. The Intimate Enemy: Loss and Recovery of Self Under Colonialism. 1983. Delhi: Oxford UP, 1990.

Parry, Ann. The Poetry of Rudyard Kipling: Rousing the Nation. Buckingham and Philadelphia: Open UP, 1992.

Peers, Douglas M. 'Privates off Parade: Regimenting Sexuality in the Nineteenth-Gentury Indian Empire.' The International History Review 20.4 (December 1998): 823-54.

Randall, Don. 'Ethnography and the Hybrid Boy in Rudyard Kipling's "Kim."' Ariel: A Review of International English Literature 27.3 (July 1996): 79-104.

- 'The Kipling Given, Ondaatje's Take: Reading Kim through The English Patient.' Journal of Commonwealth and Postcolonial Studies 5.2 (Fall 1998): 131-44.

Said, Edward. Culture and Imperialism. Knopf: New York, 1993.

—. Introduction. Kim. By Rudyard Kipling. 1901. London: Penguin, 1987. 7-46. . Orientalism. 1978. New York: Vintage, 1979.

Stanley, Peter. White Mutiny: British Military Culture in India, I825-I875. London: Hurst, 1998.

Suleri, Sara. The Rhetoric of English India. Chicago and London: U of Chicago P, 1992. Thapar, Romila. 'Imagined Religious Communities? Ancient History and the Modern Search for a Hindu Identity.' Modern Asian Studies 23.2 (1989): 209-31. 
